\title{
Acute effects of gastrocnemius muscle stretching after contusion in rats
}

\section{Efeitos agudos do alongamento muscular do gastrocnêmio após contusão em ratos}

Efectos agudos del estiramiento muscular del gastrocnemio tras contusión en ratones

Ana Carolina Brandt de Macedo',2, Julye Leiko Ywazaki', Jaqueline Pacheco², Sibelly Gonçalves ${ }^{2}$, Anna Raquel Silveira Gomes ${ }^{1}$

\begin{abstract}
I The aim of this study was to evaluate the acute effects of stretching after gastrocnemius contusion in rats. Thirty-three male Wistar rats were selected (8 weeks, 219 $\pm 35 \mathrm{~g}$ ) and divided into 4 groups: Control (CG, n=3) intact; Lesion (LG, n=10); Stretching ( $S G, n=10$ ): Lesion and Stretching ( $L S G, n=10$ ). The right gastrocnemius (RG) was submitted to contusion. Stretching on RG was performed manually, with 4 repetitions of 30 seconds each day, for 5 consecutive days, beginning 72 hour after contusion. One week later, rats were weighed and both paws were removed for investigation of muscle length, serial sarcomere number and sarcomere length. The final body weight increased in all groups. The muscle weight and length, as well as the serial sarcomere number (SSN) of LG, were higher than SG. However, the SSN of LSG was higher than SG. The sarcomere length of SG was the highest among all groups. It was concluded that the contusion and stretching did not affect body weight gain. The stretching induced sarcomerogenesis in injured muscle, but did not modify the healthy muscle.
\end{abstract} Keywords | Muscle, Skeletal/injuries; Muscle Stretching Exercises/methods.

RESUMO I O objetivo do estudo foi avaliar os efeitos agudos do alongamento após contusão do gastrocnêmio de ratos. Foram selecionados 33 ratos Wistar machos (8 semanas, 219 $\pm 35 \mathrm{~g}$ ), que foram divididos em 4 grupos: Controle (GC, n=3) - intacto; Lesão (GL, n=10); Alongamento ( $G A, n=10$ ); Lesão e Alongamento (GLA, n=10). O gastrocnêmio direito (GD) foi submetido à contusão. O alongamento do GD foi realizado manualmente, 4 repetições de 30 segundos, durante 5 dias, iniciado 72 horas após a lesão. Após uma semana, os ratos foram pesados, e os músculos de ambas as patas foram retirados para análise do peso e comprimento muscular, número e comprimento dos sarcômeros. O peso corporal final aumentou em todos os grupos. O peso, comprimento muscular e número de sarcômeros em série (NSS) do GL foram maiores que o GA. Porém, o NSS do GLA foi superior ao GA. O comprimento dos sarcômeros do GA foi maior que os demais grupos. Conclui-se que a contusão e o alongamento não interferiram no ganho de peso corporal. O alongamento induziu sarcomerogênese em músculos lesados, porém não modificou o músculo hígido.

Descritores | Músculo Esquelético/lesões; Exercícios de Alongamento Muscular/métodos.

RESUMEN I El objetivo de este estudio fue evaluar los efectos agudos del estiramiento después de la contusión del gastrocnemio de ratones. Fueron seleccionados 33 ratos Wistar machos (8 semanas, 219 $\pm 35 \mathrm{~g}$ ), divididos en 4 grupos: Control (GC, n=3) - intacto; Lesión (GL, n=10); Estiramiento ( $G E, n=10$ ); Lesiones y Estiramiento (GLE, $\mathrm{n}=10$ ). El gastrocnemio derecho (GD) fue sometido a contusión. El estiramiento del GD se realizó manualmente, 4 repeticiones de 30 segundos durante 5 días comenzando 72 horas después de la lesión. Luego de una semana, las

Study conducted at the Faculdades Integradas do Brasil (UniBrasil) - Curitiba (PR), Brazil.

'Postgraduate Program in Physical Education of Universidade Federal do Paraná (UFPR) - Curitiba (PR), Brazil.

2Physical Therapy course at UniBrasil - Curitiba (PR), Brazil. 
ratas fueron pesadas y se eliminaron los músculos de las patas para el análisis de peso y longitud muscular, número y longitud de los sarcómeros. El peso corporal final aumentó en todos los grupos. El peso, la longitud muscular y el número de sarcómeros en serie (NSS) del GL fueron superiores al GE. Sin embargo, el NSS del GLE fue superior al GE. La longitud del sarcómero del GE fue más alta que la de los otros grupos. Se concluye que la contusión y el estiramiento no afectaron a la ganancia de peso corporal. El estiramiento generó sarcomerogenesis en músculos lesionados, pero no modificó el músculo sano.

Palabras clave I Músculo Esquelético/lesiones; Ejercicios de Estiramiento Muscular/métodos.

\section{INTRODUCTION}

Contusion is a lesion caused by direct trauma on the skeletal muscle, tangentially or directly, and represents $60 \%$ of sports injuries ${ }^{1}$. It can be described as mild, moderate and severe, and it presents signs and symptoms such as pain, edema, limited movement range, muscle strength, function and gait, proportionally to the severity of the injury ${ }^{2}$.

After an acute muscle lesion, rest has been recommended, as well as cryotherapy/compression/ elevation and early mobilization ${ }^{2,3}$. Frequently, anti-inflammatory medicines are prescribed ${ }^{4-6}$, as well as actogevin shots, manipulations and exercises. However, systematic reviews point to reduced scientific evidence about the treatment ${ }^{7,8}$.

Among the several recommended exercises to treat muscle contusion, muscle stretching is usually used for rehabilitation and the practice of sports ${ }^{1,7}$. However, the effects of this exercise on the process of muscle regeneration are not clear ${ }^{9,10,11}$. According to Kannus et al. ${ }^{12}$, free movements and mobilization on the treadmill improve the orientation of collagen fibers and the atrophy caused by immobilization. Other studies with rats reported that the passive static muscle stretching may reduce muscle atrophy ${ }^{13}$, increase the cross-section area of muscle fibers and the serial sarcomere number $(\mathrm{SSN})^{14}$.

Therefore, the objective of this study was to assess the acute effects of muscle stretching after the contusion of the gastrocnemius muscle in rats.

\section{METHODOLOGY}

\section{Animals and experimental groups}

After the approval of the Ethics Committee (CEEA) (491/2010), 33 young albino rats were selected (8 to 9 weeks old), with initial body weight of $129 \pm 35 \mathrm{~g}$.
The animals were groups and kept in standard plastic cages, under controlled environmental conditions (lighting: bright/dark 12 hour cycle), with free access to water and pelleted ration.

Animals were divided into four groups: Control Group ( $\mathrm{CG}, \mathrm{n}=3$ ): the gastrocnemius muscle was not submitted to contusion and received no treatment; Lesion Group (LG, $\mathrm{n}=10$ ): the right gastrocnemius muscle (RGM) was injured, as described by Minamoto et al. ${ }^{15}$; the Stretching Group (SG, $\mathrm{n}=10$ ): RGM was not submitted to contusion, however, 72 hours after the animal arrived to the bioterium, the passive stretching of RGM began, once a day, 5 days in a role. Four repetitions of stretching were performed, and each of them lasted 30 seconds, with 30 second intervals between each repetition ${ }^{16}$ - it was repeated 4 times ${ }^{17}$; The Lesion and Stretching Group (LSG, $\mathrm{n}=10$ ): RGM was submitted to injury, and after 72 hours, stretching began according to the protocol described earlier. All of the rats in all of the groups were submitted to orthotanasia on the $8^{\text {th }}$ day (Figure 1).

\section{Protocol to cause muscle contusion}

Animals were anesthetized with intraperitoneal Ketamine $(95 \mathrm{mg} / \mathrm{kg})$ and Xylazine $(12 \mathrm{mg} / \mathrm{kg})$ and kept in ventral decubitus position. The right paw was manually immobilized, with knee extension and dorsal flexion at $90^{\circ}$ from the tibial tarsal joint. After animals were anesthetized, the contusion was in accordance with the protocol by Minamoto et al..$^{15}$.

\section{Protocol for gastrocnemius muscle stretching}

In order to stretch the RGM, animals were manually immobilized, and the maximum dorsiflexion was performed at the right paw, for 30 seconds, with 30-second intervals between each repetition ${ }^{16}$, which was repeated 4 times $^{17}$. Stretching began 72 hours after the lesion, and was conducted daily, once a day, for 5 consecutive days. 


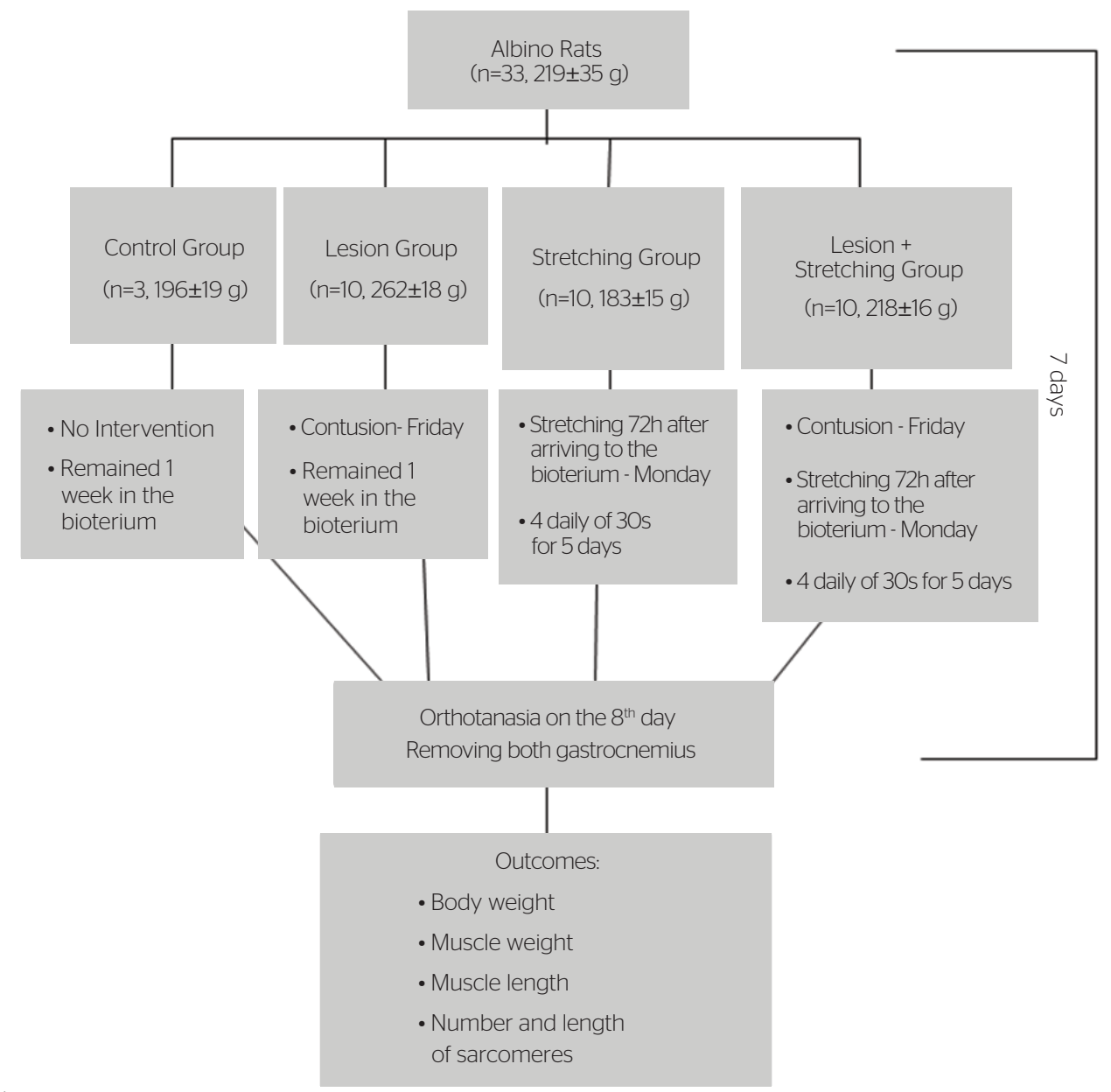

Figure 1. Study flowchart

\section{Orthotanasia of animals and muscle removal}

Twenty-four hours after the end of the experiment, animals received intraperitoneal anesthesia (Ketamine, $95 \mathrm{mg} / \mathrm{kg}$ and Xylazine, $12 \mathrm{mg} / \mathrm{kg}$ ) to remove the gastrocnemius muscles bilaterally. Afterwards, animals were submitted to orthotanasia with anesthetic overdose.

During dissection, muscles were periodically dripped with saline solution ( $\mathrm{NaCl} 0.9 \%)$. Afterwards, the muscle was weighed with a precision digital scale, and after that, the length of the muscle was measured by a digital pachymeter. Then, the gastrocnemius muscle was immersed into a glutaraldehyde solution (2.5\%) for 3 hours, and then it was transferred into a nitric acid solution (30\%) for 48 hours, being afterwards stored in glycerol (50\%).

\section{Estimation of serial sarcomeres and lenght of sarcomeres}

For the confection of histological blades, five muscle fibers were isolated from the venter of each gastrocnemius muscle, right and left sides. Afterwards, the isolated fibers were placed on a histological blade, in gelatinglycerin (Sigma) and protected by a slip. In each muscle fiber, the serial sarcomere number was identified throughout $300 \mu \mathrm{m}$, in a light microscope (100x objective, immersed). Quantification was made in a video monitor, with a video-image system attached to the microscope.

The total number and length of sarcomeres, in each isolated muscle fiber, were estimated by correlating the number of sarcomeres identified throughout $300 \mu \mathrm{m}$ of the fiber and the total length of the muscle, as described by Williams and Goldspink ${ }^{18}$. Even though there are controversies in literature, in this study, the length of sarcomeres throughout muscle fibers was considered to be homogeneous ${ }^{14}$.

\section{Statistical analysis}

In order to assess normality and homoscedasticity, the Shapiro Wilk and Levene tests were performed, respectively. Descriptive statistics for parametric and non-parametric results are expressed as 
mean \pm standard-deviation. Intra and intergroup comparisons were performed by ANOVA post hoc Tukey unequal HSD for parametric values; in case of nonparametric values, the Kruskal Wallis test was used. Values were significant when $\mathrm{p} \leq 0.05$.

\section{RESULTS}

\section{Body weight}

Significant increase was found between initial and final body weight in all of the groups (intragroup, $\mathrm{p}<0.05$, ANOVA post hoc Tukey unequal HSD). With regard to absolute weight, the final body weight of LG was higher than the one in SG $(337 \pm 28$ versus $281 \pm 28 \mathrm{~g}, \mathrm{p}=0.008)$ and LSG $(337 \pm 28$ versus $275 \pm 25 \mathrm{~g}, \mathrm{p}=0.002$, ANOVA). Concerning the relative difference in weight gain, no significant difference was found between groups. Results are described in the Table.

\section{Muscle weight}

No significant difference was found by comparing the RGM and the left muscle (LGM) (intragroup, $\mathrm{p}>0.05)$. In intergroup comparison, the RGM muscle weight in the LG was higher than in the SG $(1.89 \pm 0.17$ versus $1.33 \pm 0.13 \mathrm{~g}, \mathrm{p}=0.001$, Kruskall-Wallis). Results are demonstrated in Figure 2.

\section{Muscle strength of the gastrocnemius}

By analyzing the muscle strength of the RGM and the LGM, no intragroup significant difference was observed. In intergroup comparisons, the length of the RGM in the LG was higher in relation to the one in

Table. Effect of stretching on the body weight of rats

$\begin{array}{lcccc}\text { Groups } & \begin{array}{c}\text { initial weight } \\ (\mathrm{g}) \\ \text { Mean } \pm \text { SD }\end{array} & \begin{array}{c}\text { Final weight } \\ (\mathrm{g}) \\ \text { Mean } \pm \text { SD }\end{array} & \begin{array}{c}\text { Relative } \\ \text { difference } \\ (\%)\end{array} & \begin{array}{c}\text { p-value } \\ \text { ANOVA }\end{array} \\ \text { GC } & 196 \pm 19 & 286 \pm 19^{*} & 46,3 & 0,0006 \\ \text { LG } & 264 \pm 18 & 337 \pm 28^{* *} & 28,6 & 0,0001 \\ \text { SG } & 190 \pm 12 & 275 \pm 25^{*} & 45,1 & 0,0001 \\ \text { LSG } & 197 \pm 21 & 281 \pm 28^{*} & 43,7 & 0,0001\end{array}$

Results are mean \pm Standard-deviation. CG: Control Group; LG: Lesion Group: SG: Stretching Group; LSG: Lesion and Stretching Group. *compared to initial body weight; \#compared to SG $(p=0.0008)$ and to LSG $(p=0.002)$ the SG $(28.53 \pm 3.63$ versus $22.37 \pm 1.82 \mathrm{~mm}, \mathrm{p}=0.01$, ANOVA post hoc Tukey unequal HSD). Data are presented in Figure 3A.

\section{Estimation of the Serial Sarcomere Number}

In the comparison between the serial sarcomere number of the RGM and the LGM, no statistically significant difference was found (ANOVA post hoc Tukey).

In the intergroup comparison of the RGM, the LG was higher than the SG $(9,455 \pm 1,540$ versus $5,023 \pm 1,188$; $p=0.0001$, ANOVA post hoc Tukey unequal HSD), and the LSG was higher than the SG $(9,123 \pm 720$ versus $5,023 \pm 1,188 ; p=0.0002)$. Data are demonstrated in Figure 3B.

\section{Length of sarcomeres}

In relation to intragroup comparison, no statistically significant difference was found in any group.

In the length of sarcomeres of the RGM, a significant increase in the SG in was observed in relation to the LG $(4.60 \pm 0.77$ versus $3.03 \pm 0.18 \mu \mathrm{m}$, $\mathrm{p}=0.0008)$, in relation to the LSG $(4.60 \pm 0.77$ versus $2.96 \pm 0.17 \mu \mathrm{m}, \mathrm{p}=0.001)$ and in relation to $\mathrm{CG}$ ( $4.60 \pm 0.77$ versus $2.95 \pm 0.03 \mu \mathrm{m}, \mathrm{p}=0.001$ ) (ANOVA post hoc Tukey unequal HSD). Data are presented in Figure 3C.

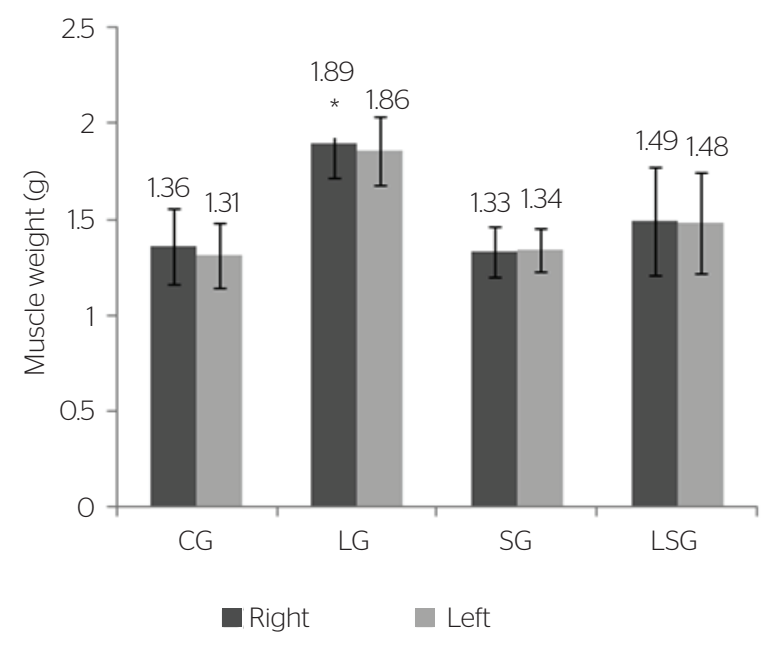

Results are meantstandard deviation. CG: Control Group; LG: Lesion Group; SG: Stretching Group: LSG: Lesion and Stretching Group. * $\mathrm{p}=0.001$ when compared to the SG. Right: right gastrocnemius muscle; Left: left gastrocnemius muscle.

Figure 2. Effect of stretching on the gastrocnemius muscle weight 


\section{DISCUSSION}

The results in this study showed increased muscle weight, muscle length and estimation of SSN in the $\mathrm{LG}$ in relation to the SG. The stretching protocol of the injured muscle provided an increment in the number of sarcomeres in relation to the non-injured group.
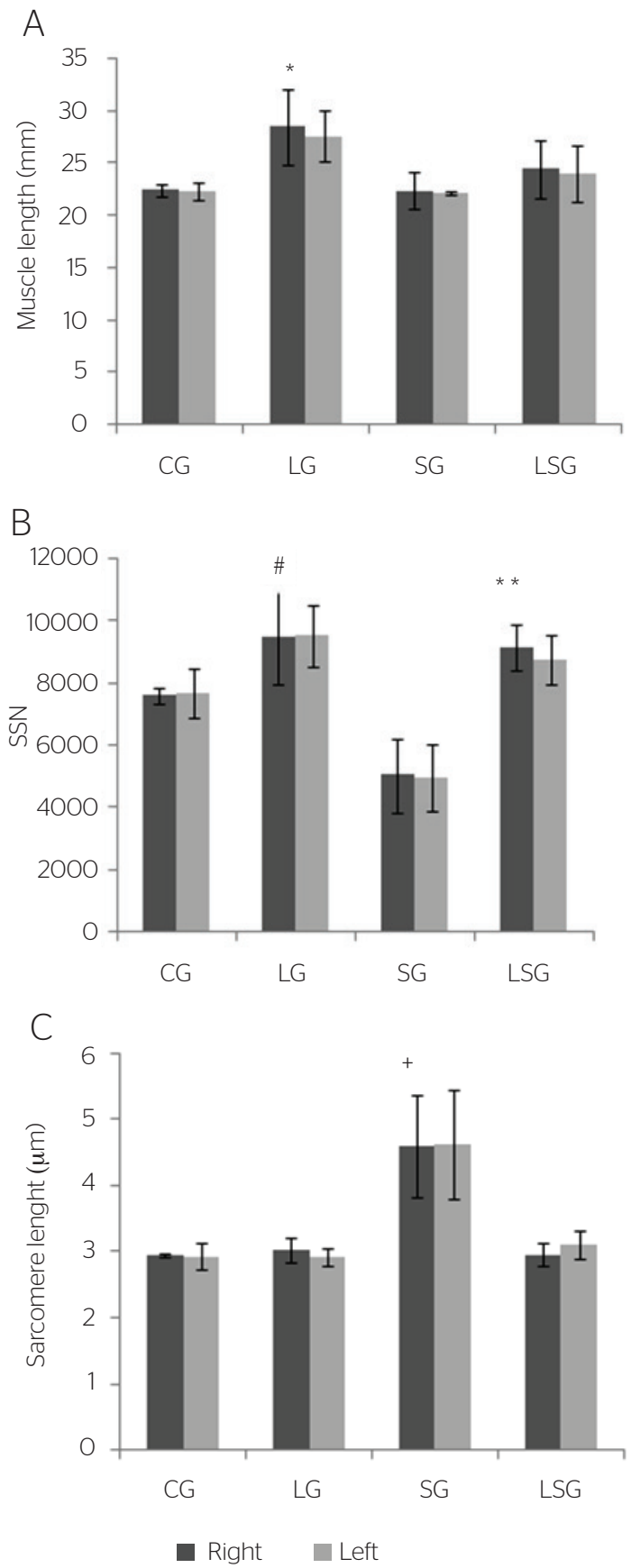

Results are mean \pm standard deviation. CG: Control Group; LG: Lesion Group; SG: Stretching Group LSG: Lesion and Stretching Group. SSN: Estimation of the serial sarcomere number. Right: right gastrocnemius muscle; Left: left gastrocnemius muscle; (A) *p<0.05 compared to the SG ( $p=0.03) ;(B) \# p<0.05$ compared to the SG and ${ }^{* *}$ when compared to the SG $(p=0.001)$; (C) $+p<0.05$ compared to the LG $(p=0.001), L S G(p=0.001)$ and CG $(p=0.04)$

Figure 3. Muscle strength, estimation of number and length of sarcomeres in the gastrocnemius of rats
Muscle fiber is able to adapt to new stimuli, therefore, it can change its volume, muscle length, number and length of the sarcomeres ${ }^{19}$.

In relation to final body weight, it was possible to observe increase in all of the groups, which is compatible with the regular body weight gain of the animal ${ }^{14}$. However, the LG presented higher body weight when compared to the SG and to the LSG. This outcome suggests that daily stretching may have interfered in body weight gain. However, relative body weight gain was not significant between groups, and this fact demonstrates that stretching did not interfere in this variable.

Muscle weight of the LG was higher when compared to the SG, which may have occurred because of the acute phase after contusion, characterized by an inflammatory period. In this case, the presence of edema is common, which may have led to increased muscle weight ${ }^{20}$.

Increased muscle weight after lesion is not in accordance with literature. While some authors found similar results in relation to this study, that is, increased muscle weight in the injured muscle ${ }^{20-22}$, others did not find any increase in the weight of the gastrocnemius muscle 48 hours after the lesion, and such lack of change was justified by the protein depletion caused by the injury ${ }^{23}$.

On the other hand, it is important to consider that body weight gain occurred in all of the groups, and both muscle weight and length increased with the increment of body weight. Besides, muscle length is not the best measure to establish the longitudinal muscle length. In that case, it is recommended to count the serial sarcomere number.

In this study, a higher number of serial sarcomeres was observed in the RGM in the LG when compared to the SG. Therefore, it is assumed that the higher final absolute body weight in the LG may have caused increased muscle weight and length, thus resulting in more serial sarcomeres ${ }^{24}$. However, relative weight gain between groups did not present significant differences. Anyway, it is not possible to suggest that the higher number of serial sarcomeres of the LG was a result of muscle contusion.

In the analysis of the length of sarcomeres in the LG, they were shorter when compared to the SG. This finding corroborates the study by Williams and Goldspink $^{25}$, who reported that changes in the serial sarcomere number imply adjustments in the length of sarcomeres. Therefore, the shorter length of sarcomeres found in the LG may have been a result of the higher 
serial sarcomere number, so there could be a great superposition of contractile filaments ${ }^{25,26}$.

On the other hand, the LSG presented higher serial sarcomere number when compared to the SG, however, these groups did not present statistical differences in relation to the CG. This outcome suggests that the injured muscle may respond differently to stretching when compared to the healthy muscle. Other researchers assessed the effect of stretching, twice a week, in the healthy soleus muscle of rats, and, after 3 weeks, they observed increased serial sarcomere number ${ }^{27}$.

In this study, it is possible to assume there were not time or stimuli enough to increment the serial sarcomere number in non-injured muscles. Previous studies showed that the immobilization stimulus in stretched muscles, for 3 to 4 weeks, led to increased muscle length by the addition of serial sarcomere number ${ }^{28,29}$. However, in this study, muscles were not immobilized in the stretched position, and they also were not maintained for 3 to 4 weeks, which is time enough for the important addition of serial sarcomere number, even when stretching is intermittent, that is, muscles are not maintained immobilized in the stretching position ${ }^{14}$.

It was surprising to find more sarcomeres in the LSG when compared to the SG. Until now, no article was found that assessed the number and length of sarcomeres after muscle lesion. Besides, there are not many articles about the effects of stretching after muscle injury.

Hwang et al. ${ }^{9}$ observed the effects of passive stretching $(5$ seconds of maintenance and 5 seconds of interval for 15 minutes) in muscles of rats in the inflammatory, regenerative and proliferative phases. These authors concluded that all of the groups submitted to stretching (initiated on the $2^{\text {nd }}, 7^{\text {th }}$, and $14^{\text {th }}$ days) presented decreased fibrosis, significant improvement of regeneration and increased muscle strength, which were more expressive on the $14^{\text {th }}$ day.

Some studies assessed the effects of immobilization in the process of muscle regeneration ${ }^{22,30}$. Järvinen et al. ${ }^{22}$ reported that mobilization leads to the faster and more intense re-epithelization of lesion borders, especially at early stages. Faria et al..$^{30}$ investigated different mobilization protocols after muscle lesion in rats. The proposed protocols were addressed at mobilizing during 5 to 8 days, with 15 to 45 -minute sessions, beginning 1 and 3 hours after the lesion. In this study, the conclusion is that the process of muscle regeneration is related to the beginning and the time of mobilization, being higher in groups that began earlier and, therefore, were mobilized for longer.
Therefore, the sarcomerogenesis observed in the LSG compared to the SG may have responded to the early beginning of mobilization, since in this study stretching began 72 hours after contusion. As to the $\mathrm{SG}$, since the muscle was at normal state, that is, not shortened, not immobilized, not injured, it is assumed that the necessary stimulus to induce the addiction of serial sarcomeres should be stronger and for a longer period, as performed in other studies ${ }^{14,27}$.

In this study, longer length of sarcomeres was found in the SG in comparison to the LSG, which is in accordance with the hypothesis that the adjustment of sarcomere length agrees with the number of sarcomeres for the muscle to develop maximum tension ${ }^{25}$.

Some limitations in this study can be indicated, such as the absence of an analysis of the cross-section area, the conjunctive tissue, the gene expression and proteins, in order to investigate the mechanisms of plasticity of injured muscles in response to the stretching stimulus.

In this study, it was observed that contusion and stretching did not interfere in the final body weight gain of the animals. Besides, the stretching protocol was sufficient to induce sarcomerogenesis in injured muscles, without interfering in the healthy muscle. However, muscles that have been only stretched, that is, not-injured, presented longer sarcomere length when compared to other groups, demonstrating that the absence of sarcomerogenesis leads to increased sarcomere length.

\section{CONCLUSION}

The outcomes of this study indicate the importance of stretching, even at the acute phase after muscle injury, in order to gain serial sarcomeres. With the proper extrapolation restrictions, the employed stretching protocol allows to suggest the clinical indication to prevent the loss of movement range, usually observed after muscle injury.

\section{REFERENCES}

1. Smith C, Kruger MJ, Smith RM, Myburg KH. The inflammatory response to skeletal muscle injury: illuminating complexities. Sports Med. 2008;38(11):947-69. 
2. Järvinen $T A H$, Järvinen $T L N$, Kääriäinen $M$, Kalimo $H$, Järvinen M. Muscle injuries: biology and treatment. Am J Sports Med. 2005;33(5):745-64

3. Oliveira NML, Gava AD, Salvini TF. O efeito da crioterapia e compressão intermitente no músculo lesado de ratos: uma análise morfométrica. Rev Bras Fisioter. 2007;11(5):403-9.

4. Lapointe $\mathrm{BM}$, Frémont $\mathrm{P}$, Côté $\mathrm{CH}$. Influence of nonsteroidal antiinflammatory drug treatment duration and time of onset on recovery from exercise-induced muscle damage in rats. Arch Phys Med Rehabil. 2003;84(5):651-5

5. Mendias CL, Tatsumi R, Allen RE. Role of cyclooxygenase-1 and -2 in satellite cell proliferation, differentiation and fusion. Muscle Nerve. 2004:30(4):497-500.

6. Mackey AL, Mikkelsen UR, Magnusson SP, Kjaer M. Rehabilitation of muscle after injury- the role of anti-inflammatory drugs. Scand J Med Sci Sports. 2012;22(4):8-14

7. Reurink G, Goudswaard GJ, Tol JL, Verhaar JA, Weir A, Moen MH. Therapeutic interventions for acute hamstring injuries: a systematic review. Br J Sports Med. 2012;46(2):103-9.

8. Mason DL, Dickens V, Vail A. Rehabilitation for hamstring injuries. Scand J Med Sci Sports. 2007:17(2):45-75.

9. Hwang JH, Ra Y, Lee KM, Lee JY, Ghil SH. Therapeutic effect of passive mobilization exercise on improvement of muscle regeneration and prevention of fibrosis after laceration injury of rat. Arch Phys Med Rehabil. 2006;87(1):20-6.

10. Kannus P. Immobilization or early mobilization after an acute softtissue injury? Phys Sport Med. 2000;28(3):1-8.

11. Järvinen MJ, Lehto MU. The effects of early mobilisation and immobilisation on the healing process following muscle injuries. Sports Med. 1993;15(2):78-89.

12. Kannus $P$, Jozsa $L$, Kvist $M$, Järvinen $T$, Järvinen $M$. Effects of immobilization and subsequent low-and high-intensity exercise on morphology of rat calf muscles. Scand J Med Sci Sports. 1998:8(3):160-71.

13. Gomes ARS, Coutinho EL, França CN, Polonio J, Salvini TF. Effect of one stretch a week applied to the immobilized soleus muscle on rat muscle fiber morphology. Braz J Med Biol Res. 2004;37(10):1473-80.

14. Coutinho EL, Gomes ARS, França CN, Oishi J, Salvini TF. Effect of a passive stretching on the immobilized soleus muscle fiber morphology. Braz J Med Biol Res. 2004;37(12):1853-61.

15. Minamoto V, Bunho SR, Salvini TF. Regenerated rat skeletal muscle after periodic contusions. Braz J Med Biol Res. 2001;34(11):1447-52.

16. Polizello JC, Carvalho LC, Freitas FC, Padula N, Shimano AC, MatielloSverzut AC. Propriedades mecânicas do músculo gastrocnêmio de ratas, imobilizado e posteriormente submetido a diferentes protocolos de alongamento. Rev Bras Med Esp. 2009;15(3):195-9.

17. Taylor DC, Dalton JC, Seaber AV, Garret WE. Viscoelastic properties of muscle-tendon units. The biomechanical effects of stretching. Am J Sports Med. 1990;18(3):300-8.

18. Williams PE, Goldspink G. Longitudinal growth of striated muscle fibers. J Cell Sci. 1971;9(3):751-67.

19. Burkholder TJ, Lieber RL. Sarcomere number adaptation after retinaculum transection in adult mice. J Exp Biol. 1998;201(Pt 3):309-16.

20. Crisco JJ, Jokl P, Heinen GT, Connell MD, Panjabi MM. A muscle contusion injury model. Biomechanics, physiology and histology. Am J Sports Med. 1994;22(5):702-10.

21. Salvini TF, Coutinho EL, Russo TL, Deluca C. One-minute bouts of passive stretching after immobilization increase sarcomerogenesis in rat soleus muscle. Braz J Morphol Sci. 2006;23(2):271-7.

22. Järvinen M. Healing of a crush in rat striated muscle. A histological study of the effect of early mobilization and on the repair processes. Acta Pathol Microbiol Scand. 1975;83(3):269-82.

23. Fisher BD, Baracos VE, Shnitka TK, Mendryk SW, Reid DC. Ultrastructural events following acute muscle trauma. Med Sci Sports Exerc. 1990;22(2):185-93.

24. Menon T, Casarolli LM, Cunha BC, Souza L, Andrade PHM, Albuquerque $\mathrm{CE}$, et al. Influência do alongamento passivo em três repetições de 30 segundos a cada 48 horas em músculo sóleo imobilizado de ratos. Rev Bras Med Esporte [on-line]. 2007:13(6):407-10.

25. Williams PE, Goldspink G. Changes in sarcomere length and physiological properties in immobilized muscle. J Anat. 1978:127(3):459-68.

26. Gordon AM.; Huxley AF, JULIAN FJ. The variation in isometric tension with sarcomere lenght in vertebrate muscle fibers. J Physiol. 1966;184(1):170-19.

27. Secchi KV, Morais CP, Cimatti PF, Tokars E, Gomes ARS. Effects of stretching and resistive exercise in rat skeletal muscle. Rev Bras Fisioter. 2008;12(3): 228-34.

28. Williams PE, Goldspink G. Connective tissue changes in immobilised muscle. J Anat. 1984:138(2):343-50.

29. Williams PE, Catanese T, Lucey EG, Goldspink G. The importance of stretch and contractile activity in the prevention of connective tissue accumulation in muscle. J Anat. 1988;158:109-14.

30. Faria FET, Ferrari R, Distefano G, Ducatti AC, Soares KF, Montebelo MIL, et al. The onset and duration of mobilization affect the regeneration in the rat muscle. Histol Histopathol. 2008;23(5):565-71 